\title{
Manajemen Risiko Investasi Pada Perbankan Syariah
}

\author{
${ }^{1}$ Adia Nur Fadilah, ${ }^{2}$ Jalaludin \\ ${ }^{1}$ Prodi Perbankan Syariah STIE Syariah Indonesia Purwakarta \\ ${ }^{2}$ STIE Syariah Indonesia Purwakarta \\ 19adianf995@gmail.com \\ 2Jalaludin.darululum@yandex.com
}

Intisari- Dalam dunia keuangan tentu resiko investasi harus diperhatikan para investor sebelum mengambil keputusan agar tidak mengalami kerugian.Pengertian resiko investasi juga perlu dipelajari dan dipahami para penanam modal agar investor tidak merasa tertipu dan yakin dengan 'untung-rugi' saat memilih jenis usaha yang kan diinvest kemudian dapat mengambil hikmah dari usaha yg dijalankan.Untuk Teknis dari manajemen resiko investasi akan kita bahas dibawah nanti.Selain pemahaman resiko investasi, Tahapan berinvestasi juga dapat diketahui dari lembaga keuangan yang investor pilih. Untuk itu tanyakanlah tahapan tahapan berinvestasi sebelum anda mengucurkan dana.Salah satu jenis investasi yang menarik untuk dilirik para investor adalah peerto-peer.Berbeda dengan cara pembiayaan tradisional, Peer-to-peer (P2P) lending menggunakan teknologi lending marketplace dan scoring. Yang dengannya investasi resiko menjadi terukur dan bagus bagi investor.Dana yang nantinya telah dikumpulkan akan disalurkan untuk para pengusaha mikro dan UKM yang memerlukan pembiayaan dengan para investor yang ingin mendanai usaha tersebut.Investor yang telah menanamkan dananya dengan sistem peer-to-peer lending tidak perlu khawatir akan resiko investasi. Karena nantinya para investor akan mendapatkan imbal hasil yang sesuai berdasarkan pertimbangan profil resiko investasi.

Kata kunci: Manajemen Risiko, Resiko Investasi, Perbankan Syariah.

Abstract - In the world of finance, investment risk must be considered by investors before making a decision not to suffer losses. Understanding investment risk also needs to be studied and understood by investors so that investors do not feel cheated and convinced of 'profit-loss' when choosing the type of business that is investigated later. can take lessons from the business that is run. For technical investment risk management we will discuss below later. In addition to understanding investment risk, investment stages can also be known from financial institutions that investors choose. For that, ask the stages of investing before you disburse funds. One an interesting type of investment for investors is peer-to-peer. Different from traditional financing methods, Peer-to-peer (P2P) lending uses marketplace lending technology and scoring. Which with risk investment becomes measurable and good for investors. Funds that will have been collected will be channeled to micro entrepreneurs and SMEs who need financing with investors who want to fund the business. Investors who have invested their funds in a peer-to-peer lending system are not need to worry about investment risks. Because later investors will get appropriate returns based on consideration of investment risk profiles.

Keywords—Risk Management., Investment Risk, Islamic Banking.

\section{Pendahuluan}

Tidak ada satu pun produk investasi di dunia ini yang aman dan bebas risiko. Semua produk mengandung risiko. Masalahnya, apakah risiko yang dihadapi besar atau kecil. Untuk itu, setiap risiko yang terkandung di dalam setiap produk investasi hendaknya tidak kita hindari, tetapi dapat kita manage sedemikian rupa sehingga meminimalisir tingkat risikonya.
Ketika kita ingin berinvestasi di pasar modal, misalnya produk saham, maka kita harus mengetahui dan memperhitungkan seberapa besar risiko yang terkandung di dalam produk tersebut. Produk investasi seperti saham memiliki risiko penurunan harga, yang pada akhirnya akan menurunkan nilai investasi yang kita miliki. Maka 


\section{EKSISBANK Vol. 3 No. 1 Juni 2019}

dari itu, penting bagi kita untuk dapat meminimalisir risikonya. ${ }^{1}$

Saat ini bermunculan berbagai produk investasi yang bisa memberikan hasil investasi yang kompetitif, tetapi masih tetap dengan risiko yang terkontrol. Seharusnya, produk-produk investasi inilah yang dimanfaatkan masyarakat sebagai sarana berinvestasi. Investasi oleh para investor merupakan permainan ekspektasi masa depan. Dikarenakan tujuan dari investor adalah memaksimalkan tingkat pengembalian (return) tanpa melupkaan faktor risiko investasi yang harus dihadapi. Tingkat pengembalian(return) adalah imbalan yang diharapkan diperoleh di masa mendatang. Sedangkan risiko adalah kemungkinan terjadinya penyimpangan dari rata-rata tingkat pengembalian yang diharapkan yang dapat diukur dari standar deviasi dengan menggunakan statistika. $^{2}$

Perlu disadari bahwa, sulit dipisahkan antara return dengan risiko investasi. Oleh karena itu perusahaan harus mampu mempertimbangkan pemilihan keputusan dalam berinvestasi. Suatu keputusan yang memiliki return yang tinggi sudah pasti berhubungan terbalik dengan risiko yang tinggi pula (high return high risk). Artinya, setiap ekspektasi di amsa datang atas satu investasi maka pasti terdapat risiko potensial akan terjadi dari investasi bersangkutan.

Inilah perbedaan dari bank konvensional dan bank syariah karena bank konvensional tidak berinvestasi pada aset berbasis ekuitas. Investor disekitar ini tentu saja menyebabkan ketidakstabilan dalam pendapatan bank syariah dan memiliki efek pada risiko likuiditas, risiko kredit, dan risiko pasar. $^{3}$

Risiko investasi didefinisikan sebagai risiko yang muncul dari partisipasi dalam keuangan atau aktivitas bisnis lain yang disebutkan dalam menyediakan dana untuk sharing modal dalam bisnis yang berisiko. Bank syariah memiliki risiko investasi pada kontrak mudharabah dan musyarakah. Bank syariah menggunakan instrument ini secara substansial berpengaruh terhadap pendapatan bank, likuiditas, dan risiko lain serta volatilitas pendapatan dan modal.

${ }^{1}$ Hestanto, "Manajemen Risiko Investasi", di akses dari website (https://www.hestanto.web.id/manajemen-risiko-investasi/). Pada tanggal $31 / 1 / 2019$.

2 Amboy Rifai, "Manajemen Risiko Investasi", di akses dari website (https://aboyrifai.blogspot.com/2018/02/manajemen-risiko-islami.html/). Pada tanggal 31/1/2019.
Salah satu yang membedakan mudharabah dan musyarakah adalah besarnya keterlibatan dalam investasi pada masa kontrak. Didalam mudharabah, bank syariah menginvestasikan uang sebagai silent partner, manajemen secara eksklusif bertanggungjawab kepada pihak lain yang biasa disebut dengan mudharib. Berbeda dengan musyarakah mitra menginvestasikan dananya dan bias sebagai silent partner atau berpartisipasi sebagai manajemen (Rustam, 2013).

\section{TELAAH/KRITIK TERHADAP FENOMENA MANAJEMEN RISIKO INVESTASI}

\section{A. Pengertian Manajemen Risiko Investasi}

Istilah investasi berasal dari bahasa Latin, yaitu investire (memakai), sedangkan dalam bahasa Inggris disebut dengan invesment. Istilah hukum investasi berasal dari terjemahan bahasa Inggris yaitu invesment of law. Dalam peraturan perundang-undangan tidak ditemukan hukum investasi tersebut, maka harus dicari dari berbagai pandangan para ahli dan kamus hukum. ${ }^{4}$

Para ahli dalam bidang investasi memiliki pandangan yang berbeda mengenai konsep teoritis tentang investasi. Fitzgeral, mengartikan investasi adalah aktivitas yang berkaitan dengan usaha penarikan sumber-sember (dana) yang dipakai untuk mengadakan barang modal pada saat sekarang, dan dengan barang modal akan dihasilkan aliran-aliran produk baru dimasa yang akan datang. Dalam definisi lain, Kamaruddin Ahmad mengemukakan bahwa yang dimaksud dengan investasi adalah menempatkan uang atau dana dengan harapan untuk memperoleh tambahan atau keuntungan tertentu atas uang atau dana tersebut.

Ensiklopedia Indonesia memberikan pengertian tentang investasi adalah penanaman uang atau modal dalam proses produksi (dengan pembelian gedung-gedung, permesinan, bahan cadangan, penyelenggaraan uang kas serta perkembangannya). Dari ketiga definisi tersebut, Salim dan Budi Sutrisno menyempurnakan definisi tentang investasi sebagai berikut: "investasi adalah penanaman modal yang dilakukan oleh investor, baik investor luar negri (asing) maupun dalam negeri (domestik) dalam berbagai bidang usaha yang terbuka untuk investasi, dengan tujuan untuk memperoleh keuntungan".

${ }^{4}$ Yeni Musfiroh , "Manajemen Investasi dan Resiko Investasi", di akses dari website (https://yenimusfiroh. wordpress.com/2013/05/25/manajemeninvestasi-dan-resiko-investasi/) Pada tanggal 31/1/2019. 


\section{EKSISBANK Vol. 3 No. 1 Juni 2019}

\section{B. Tujuan dan Jenis-jenis Investasi}

1. Tujuan investasi

Kamaruddin Ahmad, mengemukakan tiga alasan sehingga banyak orang melakukan investasi, yaitu:

a. Untuk mendapatkan kehidupan yang lebih layak dimasa yang akan datang.

b. Mengurangi tekanan inflasi.

c. Dorongan untuk menghemat pajak.

Disamping hal tersebut, orang melakukan investasi karena dipicu oleh kebutuhan akan masa depan. Selain kebutuhan akan masa depan, orang melakukan investasi karena dipicu oleh banyaknya ketidakpastian atau hal-hal lain yang tidak terduga dalam hidup ini, misalnya keterbatasan dana, kondisi kesehatan, datangnya musibah secara tibatiba, dan kondisi pasar investasi.

Agar tujuan investasi tersebut dapat tercapai maka diperlukan proses dalam mengambil suatu keputusan ketika hendak melakukan investasi, terutama keuntungan yang akan diperoleh dan risiko yang dihadapinya. Dalam kaitan ini, sharpe sebagaimana yang dikutip oleh Nurul Huda dan Mustafa Edwin Naution mengemukakan bahwa pada dasarnya ada beberapa tahapan dalam mengambil keputusan investasi, antara lain:

a. Menentukan kebijakan investasi.

Pada tahapan ini, investor menentukan tujuan investasi dan beberapa kekayaan yang dapat diinvestasikan.

b. Analisis sekuritas.

Pada tahap ini investor harus melakukan analisis sekuritas yang meliputi penilaian terhadap sekuritas secara individual atau atas beberapa kelompok sekuritas.

c. Pembentukan portofolio.

Pada tahap ini investor membentuk portofolio yang melibatkan identifikasi aset khusus mana yang akan diinvestasikan dan juga menentukan seberapa besar investasi pada tiap aset tersebut.

d. Melakukan revisi portofolio.

Pada tahap ini, berkenaan dengan pengulangan secara periodik dari tiga tahap sebelumnya. Sejalan dengan waktu, investor mungkin mengubah tujuan investasinya, yaitu berussaha membentuk portofolio baru yang lebih optimal. e. Evaluasi kinerja portofolio.

Pada tahap terakhir ini, investor melakukan penilaian terhadap kinerja portofolio secara periodik dalam arti tidak hanya return yang diperhatikan, tetapi juga resiko yang dihadapi.

2. Jenis investasi

Pada dasarnya investasi dapat digolongkan ke dalam beberapa jenis, yakni berdasarkan aset, pengaruh, ekonomi, menurut sumbernya. Dalam kaitan ini, Salim dan Budi Sutrisno menjelaskan sebagai berikut:

a. Investasi berdasarkan asetnya

Investasi ini merupakan penggolongan investasi dari aspek modal atau kekayaanya. Investasi ini dibagi kepada dua jenis, yaitu: (1) real assets atau yang biasa disebut dengan aset nyata yang termasuk kedalam konsep manajemen investasi, dimana dalam investasi dinyatakan aset riil yaitu aset yang dapat menghasilkan pendapatan dan juga mengalami aus (depresiasi) ${ }^{5}$ yang merupakan investasi yang berwujud, seperti gedung-gedung, kendaraan, dan sebagainya ${ }^{6}$; (2) financial assets, yaitu yang berupa dokumen (surat-surat berharga) yang diperdagangkan dipasar uang, seperti deposito, commercial paper, surt berharga pasar uang (SBPU), dan sebagainya. Financial assets juga diperdagangkan di pasar modal, seperti saham, obligasi, warrant, opsi, dan sebagainya.

b. Investasi berdasarkan pengaruh.

Investasi berdasarkan pengaruh dibagi nenjadi dua macam, yaitu: (1) investtasi autonomus (berdiri sendiri) yaitu investasi yang tidak dipengaruhi tingkat pendapatan, bersifat spekulatif, misalnya pembelian surat-surat berharga; (2) investasi induced (memengaruhi-menyebabkan), yakni investasi yang dipengaruhi oleh kenaikan permintaan akan barang dan jasa serta tingkat pendapatan, misalnya penghasilan transitori (penghasilan yang didapat selain dari bekerja), yaitu bunga tabungan dan sebgainya.

${ }^{5}$ Said Kelana Asnawi, “Riset Keuangan', ( Jakarta : Penerbit PT Gramedia Pustaka Utang 2005 ),10.

${ }^{6}$ Candra Wijaya,"Riset Keuangan", ( Jakarta : Penerbit PT Gramedia Pustaka Utang 2005 ), 10. 


\section{EKSISBANK Vol. 3 No. 1 Juni 2019}

c. Investasi berdasarkan sumber pembiayaan. Investasi ini dibagi kepada dua macam: (1) investasi yang bersumber dana dari dalam negeri atau PMDN yaitu Penanaman Modal Dalam Negeri yang kegiatannya menanam modal untuk melakukan usaha di wilayah negara Republik Indonesia yang dilakukan oleh penanam modal dalam negeri dengan menggunakan modal dalam negeri., investornya dari dalam negeri; ${ }^{7}$ (2) investasi yang bersumber dari modal asing, pembiayaan investasi bersumber dari investor asing.

d. Investasi berdasarkan bentuk

Investasi modal ini dibagi kepada dua bentuk, yaitu: (1) investasi langsung dilaksanakan oleh pemiliknya sendiri, seperti membangun pabrik, membangun gedung selaku kontraktor, membeli total, atau mengakuisisi perusahaan; dan (2) investasi tidak langsung yang sering disebut dengan investasi portofolio. Investasi tidak langsungdilakukan melalui pasar modal dengan instrumen surat-surat berharga, seperti saham, obligasi, reksadana beserta turunannya.

\section{Asas-asas Hukum Investasi}

Undang-undang Nomor 25 Tahun 2007 Pasal 3 Ayat (1) menentukan 10 asas dalam melaksanakan penanaman modal atau investasi, sebagai berikut:

1. Asas kepastian hukum

2. Asas keterbukaan

3. Asas akuntabilitas

4. Asas perlakuan yang sama dan tidak membeda-bedakan asal negara

5. Asas kebersamaan

6. Asas efisiensi berkeadilan

7. Asas keberlanjutan

8. Asas berwawasan lingkungan

9. Asas kemandirian

10. Asas keseimbangan kemajuan dan kesatuan ekonomi nasional

Disamping 10 asas sebagaimana tersebut diatas, Salim dan Budi Sutrisno menambah beberapa asas lagi antara lain:

1. Asas ekonomi perusahaan

2. Asas hukum internasional

3. Asas demokrasi ekonomi

4. Asas manfaat

\footnotetext{
7 Danar Ajis," Penanaman Modal Dalam Negeri (PMDN)", di ambil dari website, (https://danarajis.wordpress.com/ 2013/06/15 /penanaman-modaldalam-negeri-pmdn/), pada tanggal 2/6/2019.
}

5. Asaqs nondiskriminasi

6. Risiko Investasi

Ada dua unsur yang selalu melekat pada setiap investasi, yaitu hasil (return) dan risiko (risk). Menurut Panji Anoraga dan Piji Pakarti, dalam melaksanakan investasi, seorang investor diharapkan memahami adanya beberapa risiko, sebagai berikut: (1) risiko finansial, yaitu risiko yang diterima investor akibat dari ketidakmampuan emiten (saham/obligasi) memenuhi kewajiban pembayaran dividen (bunga) serta pokok investasi; (2) risiko pasar, yaitu akibat menurunnya harga pasar substansial baik keeseluruhan saham maupun saham tertentu akibat tingkat inflasi ekonomi, keuangan negara, perubahan manajemen perusahaan, atau kebijakan pemerintah dalam bidang ekonomi; dan (3) risiko psikologis, yiatu risiko bagi investor yang bertindak secara emosional dalam menghadapi perubahan harga saham berdasarkan optimisme dan pesimisme yang dapat mengakibatkan kenaikan dan penurunan harga saham.

Timbulnya resiko investasi bersumber dari beberapa faktor. Menurut Kamaruddin Ahmad, faktor-faktor risiko ini dapat terjadi bersamaan atau hanya muncul dari salah satu saja. Risiko tersebut antara lain: (1) risiko tingkat bunga, terutama jika terjadi kenaikan; (2) risiko daya beli, disebabkan inflasi; (3) risiko bear dan bull, tren pasar turun atau naik; (4) risiko manajemen, kesalahan/kekeliruan dalam pengelolaan; (5) risiko kegagalan, keuangan perusahaan kearah kepailitan; (6) risiko likuiditas, kesulitan pencairan/pelepasan aktiva; (7) risiko penarikan, kemungkinan pembelian kembali aset/surat berharga oleh emiten; (8) risiko konversi, keharusan penukaran atau aktiva; (9) risiko politik, baik internasional maupun nasional; (10) risiko industri, munculnya saingan produk homogen.

Menurut Peraturan Bank Indonesia (PBI) risiko investasi ekuitas (equity investment risk) adalah risiko akibat bank ikut menanggung kerugian usaha nasabah yang dibiayai dalam pembiayaan bagi hasil berbasis profit and loss sharing. ${ }^{8}$

Risiko ini timbul apabila bank memberikan pembiayaan berbasis bagi hasil kepada nasabah di mana bank ikut menanggung risiko atas kerugian usaha nasabah yang dibiayai (profit and loss sharing). Dalam hal ini, perhitungan bagi hasil tidak hanya didasarkan atas jumlah pendapatan atau penjualan yang diperoleh nasabah, namun dihitung

8 Bambang Rianto Rustam, "Manajemen Risiko Perbankan Syariah di Indonesia", (Jakarta: Salemba Empat, 2013), 259. 


\section{EKSISBANK Vol. 3 No. 1 Juni 2019}

dari keuntungan usaha yang dihasilkan nasabah. Apabila usaha nasabah mengalami kebangkrutan, jumlah pokok pembiayaan yang diberikan bank kepada nasabah tidak akan diperoleh kembali.

Inilah perbedaan dari bank konvensional dan bank syariah karena bank konvensional tidak berinvestasi pada aset berbasis ekuitas. Investasi di sektor ini tentu saja menyebabkan ketidakstabilan dalam pendapatan bank syariah dan memiliki efek pada risiko likuiditas, risiko kredit, dan risiko pasar.

\section{TELAAH/KRITIK TERHADAP FENOMENA PROFIL RISIKO}

Risiko investasi didennisikan sebagai risiko yang muncul dari partisipasi dalam keuangan atau aktivitas bisnis lain yang disebutkan dalam kontrak dan ikut serta dalam menyediakan dana untuk sharing modal dalam bisnis yang berisiko. Bank syariah memiliki risiko investasi pada kontrak mudharabah dan musyarakah. Bank syariah menggunakan instrumen ini secara substansial berpengaruh terhadap pendapatan bank, likuiditas, dan tisiko lain serta volatilitas pendapatan dan modal. ${ }^{9}$

Salah satu yang membedakan mudharabah dan musyarakah adalah besarnya keterlibatan dalam investasi pada masa kontrak. Didalam

mudharabah, bank syariah menginvestasikan uang sebagai silent partner, manajemen secara eksklusif bertanggung jawab kepada pihak lain yang biasa disebut mudharib. Berbeda dengan musyarakah mitra menginvestasikan dananya dan bisa sebagai silent partner atau berpartisipasi sebagai manajemen.

Perbedaan utama dari risiko investasi mudharabah dan musyarakah adalah bahwa dalam pembiayaan mudharabah bila usaha yang dibiayai nasabah mengalami kerugian, maka bank syariah akan menanggung semua kerugian dan bank tidak bisa mewajibkan nasabah yang dibiayai untuk mengambil tindakan yang diperlukan untuk menghasilkan tingkat kembalian sebagaimana yang diharapkan. Situasi ini tentu saja dapat dimanfaatkan pengguna dana. Kelemahan lain dari mudharabah bahwa nasabah sebagai pengguna dana memiliki kecenderungan untuk overstated (lebih menekankan) pengeluaran karena tingkat pengeluaran ini merupakan beban bank sementara pengembalian konsumsi di tangan pengusaha.

Kondisi tersebut berbeda sekali dengan musyarakah di mana pengusaha juga memiliki

\footnotetext{
${ }^{9}$ Bambang Rianto, Manajemen Risiko. 260.
}

modal yang dipertaruhkan. Kedua kontrak ini menggunakan instrumen bagi hasil dengan demikian tidak memberikan kembalian tetap, tetapi secara eksplisit rawan terkena gangguan dalam peristiwa kerugian (gangguan modal). Greuning dan Iqbal $^{10}$ menyatakan bahwa risiko investasi ini memiliki beberapa fitur berbeda, yaitu sebagai berikut:

1. Sifat investasi ekuitas memerlukan pengawasan mendalam untuk mengurangi asimetri informasi. Langkah langkah ini termasuk pengungkapan keuangan yang benar, keterlibatan lebih dekat dengan proyek, transparansi dalam pelaporan, dan pengawasan pada semua tahapan pelaksanaan proyek dari penilaian sampai selesai. Oleh karena itu, bank syariah perlu memainkan peran aktif dalam pengawasan.

2.Mudharabah dan musyarakah adalah perjanjian pembagian keuntungan dan kerugian serta menghadapi risiko hilangnya modal walau dengan pengawasan yang memadai. Tingkat risiko relatif lebih tinggi dibandingkan dengan investasi lain dan bank syariah harus sangat berhati hati dalam mengevaluasi dan memilih proyek untuk mengurangi potensi kerugian.

3. Investasi ekuitas selain investasi pasar saham tidak memiliki pasar sekunder yang mengakibatkan besarnya biaya untuk keluar lebih awal. Tidak likuidnya investasi tersebut dapat menyebabkan kerugian pada bank.

4. Investasi ekuitas mungkin tidak memberikan pendapatan yang stabil dan keuntungan modal mungkin satu satunya pengembalian. Sifat tidak pasti dari arus kas membuatnya sulit untuk memperkirakan dan mengelolanya.

Tingkat risiko investasi ini sangat tinggi sehingga karekteristik risiko investasi ini harus menjadi pertimbangan dalam penilaian risiko. Risiko investasi ini harus diperhatikan kualitas mitra, jenis, dan aktivitas bisnis yang mendasarinya serta keberlangsungan operasional usaha. Menurut sifatnya, investasi ini sangat berhubungan dengan risiko yang berhubungan dengan aktivitas bisnis dan operasi mudharib atau mitra musyarakah.

Evaluasi risiko investasi menggunakan instrumen bagi hasil dari mudharabah, musyarakah, profil risiko mitra potensial (mudharib atau mitra musyarakah) adalah krusial dipertimbangkan untuk dilakukan uji kelayakan. Uji kelayakan sangat penting untuk memenuhi tanggung jawab bank

\footnotetext{
${ }^{10}$ Bambang Rianto, Manajemen Risik, 260.
} 


\section{EKSISBANK Vol. 3 No. 1 Juni 2019}

sebagai wakil dalam memegang amanah dari investor pemegang rekening dana investasi pihak ketiga atau DPK merupakan dana yang diperoleh dari masyarakat, dalam arti masyarakat sebagai individu, perusahaan, pemerintah, rumah tangga, koperasi, yayasan, dan lain-lain baik dalam mata uang rupiah maupun dalam valuta asing. Pada sebagian besar atau setiap bank, dana masyarakat ini merupakan dana terbesar yang dimiliki oleh bank. Hal ini sesuai dengan fungsi bank sebagai pennghimpun dana dari masyarakat. ${ }^{11}$ yang berbasis profit and loss sharing (Mudharabah). Profit resiko termasuk catatan masa lalu dari tim manajemen dan kualitas rencana bisnis dan termasuk pula aspek sumber daya insani (SDI) serta aktivitas mudharabah dan musyarakah yang disampaikan.

Faktor faktor yang berhubungan dengan aspek legal juga perlu diperhatikan karena memengaruhi kinerja investasi dan harus dipertimbangkan pula dalam aspek evaluasi resiko Faktor faktor termasuk kebijakan tarif, kuota, pajak, dan subsidi memiliki pengaruh ada kualitas dan Viabilitas investasi. Transaksi yang bersifat investasi (Mudharabah, musyarakah) ini harus dilakukan secara hati hati karena berpotensi mengurangi pokok investasi. Dengan demikian, aspek hukum yang menimpa nasabah juga berpotensi mengikat bank karena kedudukannya sebagai mitra.

Selain itu, bank syariah juga bisa terekspos risiko kekurangan informasi yang dapat dipercaya sebagai dasar penilaian investasi seperti ketidak cukupan sistem pengendalian keuangan. Misalnya, informasi finansial secara lengkap dan akurat untuk memitigasi risiko. Untuk itu, bank syariah harus proaktif dalam memantau posisi dan kondisi keuangan nasabah.

Meskipun alokasi profit bisa disetujui di depan secara tepat. Akan tetapi,bank syariah harus bersiap untuk penundaan dan variasi pola arus kas dan kemungkinan hambatan alokasi profit ini selalu mempersiapkan diri dalam exit strategy (strategi untuk keluar). Meskipun hal tersebut tidak sama dengan risiko kredit dalam terminologi konvensional, tetapi investasi mudharabah dan musyarakah ini memiliki kemungkinan lebih krusial dari risiko kredit karena kemungkinan risiko terhadap modal.

\footnotetext{
${ }^{11}$ Manda,'Dana Pihak Ketiga”, diakses dari website (http://artikaamanda blogspot.com/2012/04/dana-pihak-ketiga.html), pada tanggal 2/6/2019.
}

IV. TELAAH/KRITIK TERHADAP FENOMENA PRINSIPPRINSIP ISLAMIC FINANCIAL SERVICES BOARD

Islamic Financial Service Board (IFSB) adalah suatu lembaga internasional yang didirikan pada tahun 2002. IFSB berfungsi sebagai lembaga pengatur dan pengawas (regulatory and supervisory Agency) yang mengembangkan dan menetapkan standar internasional di industri jasa keuangan Islam. IFSB juga aktif terlibat dalam mempromosikan kesadaran dan edukasi masyarakat mengenai berbagai isu yang memiliki dampak di bidang jasa keuangan Islam.

IFSB melakukan sidang Dewan sebanyak 2 (dua) kali setahun dan Sidang Umum sebanyak 1 (satu) kali setahun. Keanggotaan IFSB terdiri dari full member, associate member, dan observer member. Jumlah anggota penuh IFSB sebanyak 16 negara, yaitu: Bahrain, Brunei, Mesir , Indonesia , Iran , Islamic Development Bank , Jordania , Kuwait , Malaysia, Pakistan, Qatar, Saudi Arabia, Sudan , Uni Emirat Arab , Bangladesh dan Singapura. IFSB berkedudukan (Kantor Pusat) di Kuala Lumpur, Malaysia. Adapun Prinsip-prinsip Islamic Finansial Services Board Sebagai Berikut :

a. Bank syariah harus memiliki strategi, manajemen risiko, dan proses pelaporan yang memadai sehubungan dengan karekteristik risiko investasi termasuk investasi Mudharabah dan musyarakah.

b. Bank syariah harus memastikan metodologi valuasi yang tepat dan konsisten serta harus Menilai potensi dampak dari metode perhitungan dan alokasi laba. Metode tersebut harus disepakati bersama antara bank syariah dengan mitra mudharib atau musyarakah.

c. Bank syariah harus mendefinisikan dan menetapkan strategi keluar dalam kegiatan investasi modal mereka termasuk kondisi perpanjangan dan pengembalian atas investasi mudharabah dan musyarakah berdasarkan persetujuan dari DPS bank syariah tersebut.

Pada pertimbangan operasional hendaknya sudah siap dengan suatu kerangka kerja Manajemen Risiko Kredit, mencakup; identifikasi, pengukuran, pemantauan, pelaporan serta pengendalian risikorisiko kredit. Kecukupan modal (adequate capital) harus disediakan untuk menopang risiko kredit yang diasumsikan. LKI juga harus mematuhi hukum, ketentuan yang relevan serta prinsip kehati-hatian terhadap kondisi dalam pelaksanakan kegiatan pembiayaan meliputi: 
a. Prinsip pertama

Bank syariah harus memiliki strategi, manajemen risiko, dan proses pelaporan yang memadai sehubungan dengan karekteristik risiko investasi termasuk investasi mudharabah dan musyarakah.

Bank syariah harus mendefinisikan tujuan, kriteria, investasi yang menggunakan instrumen bagi hasil, termasuk tipe investasi, toleransi risiko, kembalian investasi, dan jangka waktu. Misalnya, struktur musyarakah bisa memberikan opsi untuk pelunasan jika bank syariah sebagai pemberi dana memiliki hak kontraktual untuk mensyaratkan mitranya membeli secara periodik dalam kontrak terpisah, dalam proporsi hak bank syariah dalarn investasi sebesar nilai bersih aset jika kontrak spesifik dalam kesepakatannya.

Bank syariah harus melakukan pengkajian ulang terhadap kebijakan, prosedur, dan Struktur manajemen yang tepat untuk evaluasi dan mengelola risiko termasuk akuisisi dan keluar dari investasi bagi hasil. Bank syariah harus memastikan infrastruktur yang diperlukan dan kapasitas untuk memonitor secara berkesinambungan kinerja dan operasi perusahaan. Termasuk evaluasi kepatuhan syan'ah, kecukupan pelaporan keuangan, pertemuan periodik dengan mitra, dan dokumentasi yang baik dari pertemuan itu. bank syariah harus mengidentifikasi dan memantau transformasi risiko pada tahapan yang berbeda dari siklus investasi. Sebagai contoh, usaha itu membutuhkan inovasi produk dan jasa di pasar. Bank syariah yang memiliki instrumen pembiayaan yang berbeda (salah satunya adalah musyarakah) pada tahapan kontrak yang berbeda harus memiliki prosedur dan pengendalian yang tepat karena bisa memberikan peningkatan risiko.

Bank syariah harus menganalisis dan menentukan faktor faktor yang memungkinkan dan berpengaruh pada volume dan timing cash flow yang diharapkan baik untuk return dan capital gains (tambahan keuntungan) yang meningkat dari investasi, bank syariah harus menggunakan teknik mitigasi risiko yang memenuhi ketentuan syariah, yang mengurangi dampak dari berkurangnya investasi. Hal ini termasuk Penggunaan perlindungan yang diizinkan dari mitra. ${ }^{12}$

\section{b. Prinsip kedua}

Bank syariah harus memastikan metodologi valuasi yang tepat dan konsisten serta harus menilai potensi dampak dari metode perhitungan dan alokasi laba. Metode tersebut harus disepakati bersama antara lembaga keuangan dengan mitra Mudharib atau musyarakah.

Bank syariah harus sepakat dengan metode penilaian dan akuntansi yang diterapkan mudharib dan atau mitra musyarakah. Sebelum bank syariah memasuki beragam perjanjian dengan metode valuasi yang tepat dan periode di mana laba harus dikalkulasi dan dialokasi ke dalam praktik yang digunakan di pasar dan fitur likuiditasnya. Penilaian dan penerapan akuntansi memiliki peranan penting dalam mengukur kualitas investasi khususnya pada entitas swasta, di mana kuotasi harga independen tidak tersedia atau tidak cukup jumlahnya untuk menjadi dasar yang bermakna untuk likuiditas atau penilaian pasar. Metode yang tepat dan disepakati untuk diaplikasikan menentukan laba investasi bisa dibentuk dalam besaran persentase atau gross dan nett profit (laba bersih dan kotor) yang dihasilkan dalam mudharabah atau bisnis musyarakah dengan syarat yang saling menguntungkan. Sebuah kasus di mana ada perubahan kontribusi di musyarakah, maka perubahan kontribusi itu harus dinilai dengan harga wajar atau dalam dasar persetujuan yang saling menguntungkan.

Bank syariah harus menilai dan mengukur risiko yang berkait dengan potensi manipulasi dari pelaporan hasil yang bisa berujung pada overstatement atau understatement dari pendapatan hasil partnership. Pelaporan pendapatan bisa saja gross atau net. Iika ada alasan dalam praktis dilakukan perataan laba selama periode akuntansi dan pembentukan escrow account (rekening wasiat) untuk menahan porsi laba tertentu selama siklus ekuitas investasi yang telah diakui dan disetujui oleh seluruh pihak yang berinvestasi, bank syariah akan memasukkan dampak yang potensial ke dalam pendapatan bank syariah keseluruhan.

Bank syariah dapat menyetujui mudharib atau mitra musyarakah untuk terlibatnya pihak independen melakukan audit dan valuasi dari investasi. Asalkan dilakukan dengan benar dan sempurna, pengukuran ini akan membantu untuk memastikan transparansi dan objektivitas

\footnotetext{
${ }^{12}$ Bambang Rianto, “Manajemen Risiko”,261.
} 


\section{EKSISBANK Vol. 3 No. 1 Juni 2019}

penilaian dan distribusi laba dan penentuan jumlah yang harus ditebus.

c. Prinsip ketiga

Bank syariah harus mendefinisikan dan menetapkan strategi untuk keluar dalam kegiatan investasi modal mereka termasuk kondisi perpanjangan dan pengembalian atas investasi mudharabah dan musyarakah berdasarkan persetujuan dari DPS lembaga keuangan tersebut.

Bank syariah harus membentuk kriteria strategi untuk keluar, termasuk penebusan ekuitas investasi dan diinvestasi investasi yang kinerjanya tidak memuaskan. Kriteria termasuk rute alternatif dan waktu untuk keluar. Ada kasus kerugian di mana bisnis membaik dan prospektif, bank syariah dapat melakukan penambahan jangka Waktu. Ekspektasi bank syariah harus berdasarkan penilaian yang masuk akal dan dapat dipercaya bahwa akan ada turn around dalam bisnis itu yang terlihat pada hasil akhir dan ada keyakinan bahwa investasi akan pulih dalam waktu tertentu dan menghasilkan keuntungan. Bank syariah harus meyakini keberlangsungan usaha, perusahaan tempat investasi dilakukan karena bank syariah mungkin tidak selalu mempunyai likuiditas yang diperlukan untuk memungkinkan menghasilkan distribusi laba. Oleh karena itu, bank syariah harus setuju dengan mitra investasi untuk metode perlakuan laba ditahan yang dilakukan oleh investee (perusahaan tempat investasi dilakukan).

\section{KESIMPULAN}

Secara umum risiko dapat diartikan sebagai suatu keadaan yang dihadapi seseorangan atau perusahaan dimana terdapat kemungkinan yang merugikan. Bagaimana jika kemungkinan yang dihadapi dapat memberikan keuntungan yang sangat besar sedangkan kalaupun rugi hanya sekali saja, misalnya membeli lotre. Jika beruntung maka akan mendapatkan hadiah yang sangat besar tetapi jika tidak beruntung uang yang digunakan membeli lotre relative kecil. Risiko investasi didennisikan sebagai risiko yang muncul dari partisipasi dalam keuangan atau aktivitas bisnis lain yang disebutkan dalam kontrak dan ikut serta dalam menyediakan dana untuk sharing modal dalam bisnis yang berisiko. Bank syariah memiliki risiko investasi pada kontrak mudharabah dan musyarakah. Bank syariah menggunakan instrumen ini secara substansial berpengaruh terhadap pendapatan bank, likuiditas, dan tisiko lain serta volatilitas pendapatan dan modal. Tujuan dari manajemen risiko investasi pada suatu perbankan ialah Untuk mendapatkan kehidupan yang lebih, layak dimasa yang akan datang, mengurangi tekanan inflasi, dorongan untuk menghemat pajak, selain dari tujuan ada beberapa tahapan dalam berinvestasi yaitu: menentukan kebijakan investasi, analisis sekuritas, Pembentukan portofolio, melakukan revisi portofolio, evaluasi kinerja portofolio.

Salah satu yang membedakan mudharabah dan musyarakah adalah besarnya keterlibatan dalam investasi pada masa kontrak. Didalam mudharabah, bank syariah menginvestasikan uang sebagai silent partner, manajemen secara eksklusif bertanggung jawab kepada pihak lain yang biasa disebut mudharib. Berbeda dengan musyarakah mitra menginvestasi $\neg$ kan dananya dan bisa sebagai silent partner atau berpartisipasi sebagai manajemen. Perbedaan utama dari risiko investasi mudharabah dan musyarakah adalah bahwa dalam pembiayaan mudharabah bila usaha yang dibiayai nasabah mengalami kerugian, maka bank syariah akan menanggung semua kerugian dan bank tidak bisa mewajibkan nasabah yang dibiayai untuk mengambil tindakan yang diperlukan untuk menghasilkan tingkat kembalian sebagaimana yang diharapkan. Situasi ini tentu saja dapat dimanfaatkan pengguna dana. Kelemahan lain dari mudharabah bahwa nasabah sebagai pengguna dana memiliki kecenderungan untuk overstated (lebih menekankan) pengeluaran karena tingkat pengeluaran ini merupakan beban bank sementara pengembalian konsumsi di tangan pengusahaan.

Islamic Financial Service Board (IFSB) adalah suatu lembaga internasional yang didirikan pada tahun 2002. IFSB berfungsi sebagai lembaga pengatur dan pengawas (regulatory and supervisory Agency) yang mengembangkan dan menetapkan standar internasional di industri jasa keuangan Islam. IFSB juga aktif terlibat dalam mempromosikan kesadaran dan edukasi masyarakat mengenai berbagai isu yang memiliki dampak di bidang jasa keuangan Islam.

\section{UCAPAN TERIMA KASIH}

Terima kasih Kepada Allah SWT yang telah memberikan saya kesehatan untuk mengerjakan jurnal ini, dan Terima kasih juga kepada kedua orang tua saya yang telah mendoakan anak nya agar 


\section{EKSISBANK Vol. 3 No. 1 Juni 2019}

cepat selesai tugasnya dan kepada rekan-rekan saya yang telah membatu saya atas pengerjaan tugas ini. Terimakasih atas seseorang yang sudah mendorong saya agar selalu semangat atas pengerjaan tugas jurnal ini. Terimakasih kepada dosen saya yang memberikan tugas yang sangat luar biasa.

\section{REFERENSI}

[1] Antonio, M.S.2001.Bank Syariah dari Teori ke Praktik. Jakarta: Gema Insani Press.

[2] Asanawi Kelana Said , Riset Keuangan, Jakarta : Penerbit PT Gramedia Pustaka Utang 2005.

[3] Hestanto, Manajemen Risiko Investasi , di akses dari website https://www.hestanto.web.id/manajemenrisiko-investasi/. pada tanggal 31/1/2019.
[4] Musfiroh Yeni, Manajemen Investasi dan Resiko Investasi, di-akses-dari-websithttps://yenimusfiroh.wordpress.com/2013/ 05/25/manajemen-investasi-dan-resikoinvestasi/ Pada tanggal 31/1/2019.

[5] Rifai Amboy, Manajemen Risiko Investasi, di akses dari websitehttps://aboyrifai.blogspot.com/2018/02/manaje men-risiko-islami.html/. Pada tanggal 31/1/2019.

[6] Ririz Riska, Resiko Dalam Investasi,di akses dari website http://rizkaririz.blogspot.com/2012/10/makalah-resikodalam-investasi.html Pada tanggal 31/1/2019.

[7] Rustam Rianto Bambang, Manajemen Risiko Perbankan syariah di Indonesia, jakarta Salemba Empat, 2013.

[8] Wijaya Chandra, Riset Keuangan, Jakarta : Penerbit PT Gramedia Pustaka Utang 2005. 